\author{
E-ISSN: 2469-6501 \\ VOL: 8, ISSUE: 2 \\ February/2022 \\ DOI: http://dx.doi.org/10.33642/ijbass.v8n2p3 \\ (c) (7) \\ https://creativecommons.org/licenses/by/4.0/
}

\title{
The Effect of Competence and Internal Control On the Performance of Follow-Up of the Ministry of Cooperatives and Small and Medium Enterprises Through Organizational Commitment
}

\author{
Nadya Putri Ayunda1, Bomer Pasaribu², Iwan Kurniawan Subagja ${ }^{3}$ \\ Universitas Krisnadwipayana \\ Campus Unkris Jatiwaringin \\ PO BOX 7774/Jat CM Jakarta 13077, Indonesia \\ Email: nadyaputriayunda@gmail.com ${ }^{1}$ \\ Indonesia
}

\section{ABSTRACT}

The low performance of government agencies in following up audit results of Badan Pemeriksa Keuangan RI (BPK-RI) reflects their quality in realizing good governance. This study aims to analyze the effect of competence, internal control, and organizational commitment on the performance of follow-up of the Ministry of Cooperatives and Small and Medium Enterprises, either directly or indirectly. Data were collected through questionnaires and hypothesis testing was carried out using path analysis and Sobel test. The results showed that: (1) competence and internal control simultaneously had a positive and significant effect on organizational commitment; (2) competence partially had a positive and insignificant effect on organizational commitment; (3) internal control partially had a positive and significant effect on organizational commitment; (4) competence, internal control, and organizational commitment simultaneously had a positive and significant effect on followup performance; (5) competence partially had a positive and significant effect on follow-up performance; (6) internal control partially had a positive and significant effect on follow-up performance; (7) organizational commitment partially had a positive and significant effect on follow-up performance; (8) organizational commitment did not mediate the relationship between competence and follow-up performance, and (9) organizational commitment partially mediated the relationship between internal control and follow-up performance.

\section{Keywords: Competence, Internal Control, Organizational Commitment and Follow-up Performance}

\section{Introduction}

The preamble to the 1945 Constitution states that one of the goals of the State of Indonesia is to promote public welfare. That is, the administration of state government is intended to create a prosperous society. In carrying out government functions, the state has consequences for the emergence of rights and obligations related to state finances. The President as Head of Government holds the power to manage state finances as part of government power. To assist the President, some of these powers are delegated to the Minister of Finance as Fiscal Manager and Government Representative in the ownership of separated state assets, as well as to the Minister/Head of Institutions as Budget Users/Property Users of the ministries/institutions they lead. Based on the 1945 Constitution Article 23 Paragraph (1), the management of state finances is embodied in the State Revenue and Expenditure Budget (APBN) which is determined annually by law and is carried out openly and responsibly for the greatest prosperity of the people. After the APBN is stipulated in detail by law, its implementation is further elaborated by a Presidential Decree as a guideline for ministries/agencies in budget execution.

Law of the Republic of Indonesia Number 15 of 2004 concerning Audit of State Finance Management and Accountability states that to support the realization of good governance, state finances need to be managed in an orderly manner, complying with laws and regulations, efficient, economical, effective, transparent, and accountable answer with due regard to a sense of justice and propriety. Therefore, it is necessary to carry out an examination of the management of state finances based on audit standards by the Supreme Audit Agency of the Republic of Indonesia (BPK-RI) which is free and independent under the mandate of the 1945 Constitution Article 23E Paragraph (1).

BPK-RI Regulation Number 1 of 2017 concerning State Financial Audit Standards states that after completing the audit, BPK-RI prepares an Audit Result Report (LHP) in the form of a written report submitted to the audited agency (auditee). In respect of the LHP submitted by BPK-RI, the leadership of the Government Agency as the auditee is required to provide answers, explanations, and follow up on the recommendations contained in the LHP no later than 60 (sixty) days after the LHP is received. BPK-RI then monitors and reviews the follow-up actions of the auditees periodically and submits the results of the monitoring to the relevant auditees along with representative institutions and heads of government to increase the effectiveness of reporting audit results and assist the government in improving governance.

To facilitate the management of follow-up monitoring, BPK-RI has also developed a Follow-Up Monitoring Information System (SIPTL) to document, administer, and process monitoring data. However, Suwiknyo (2017) stated that the agency's compliance in following up on the recommendations of BPK-RI findings was not optimal. This is evidenced by the Summary of Semester Examination Results (IHPS) which contains the results of follow-up monitoring of 
International Journal of Business and Applied Social Science

\author{
E-ISSN: 2469-6501 \\ VOL: 8, ISSUE: 2 \\ February/2022 \\ DOI: http://dx.doi.org/10.33642/ijbass.v8n2p3 \\ (c) (i) \\ https://creativecommons.org/licenses/by/4.0/
}

all agencies examined by BPK-RI. Whereas the level of compliance of this agency is important because it reflects its quality in accounting for the state budget (BPK-RI, 2016).

This shows that in general, the performance of the audited agencies (auditees) in completing the follow-up to the results of the BPK-RI examination is still minimal. As for what is meant by performance according to Mangkunegara (2006) is work performance or actual achievement achieved. The lack of performance in completing the follow-up to the results of the BPK-RI examination shows that the auditee is still not fast and responsive even though every year BPK-RI will issue an LHP. So when the old recommendations have not been followed up and BPK-RI then issues new recommendations on the results of the audit in the following year, finally the recommendations that need to be followed up by the auditee become piled up. This low follow-up rate is the reason for the importance of improving agency performance in completing the follow-up to the results of the BPK-RI examination. The implementation of follow-up on the results of the examination is part of efforts to improve government management and failure to implement it is a waste in the use of state financial resources and apparatus resources (Ministry of Administrative Reform, 2009).

The Ministry of Cooperatives and SMEs is a government agency tasked with administering affairs in the field of cooperatives and micro, small and medium enterprises. Based on the Monitoring Results Report on the Follow-Up (LHP PTL) of the Recommendations for the 2017-2021 BPKRI Examination Results, the level of compliance of the Ministry of Cooperatives and SMEs in completing the followup to the results of the BPK-RI examinations tends to be low and stagnant in 2017 and early 2018, namely in around 50\% and fluctuated to $73.99 \%$ in the first semester of 2021 . Whereas since 2016, BPK has targeted the compliance level of state agencies that manage finances to reach $75 \%$ by 2020 . This means that the Ministry of Cooperatives and SMEs still need to improve its performance in completing the follow-up to the results of the BPK-RI examination to realize good governance. Because this percentage is not solely a compliance issue but also illustrates the wastage of state resources by the auditee.

Moreover, the enactment of Presidential Regulation Number 96 of 2020 concerning the Ministry of Cooperatives and Small and Medium Enterprises which simplifies the organizational structure and work procedures of the Ministry of Cooperatives and Small and Medium Enterprises, of course, has an impact on the unclear responsibility for completing the follow-up to the recommendations of the BPK-RI examination results at the Ministry. Cooperatives and SMEs. Therefore, it is important to conduct further research at the Ministry of Cooperatives and SMEs so that the level of compliance with the completion of the follow-up to the results of the BPK-RI examination can continue to increase to reflect the realization of good governance.
The follow-up performance of the Ministry of Cooperatives and SMEs cannot be separated from the performance of the employees who are responsible for handling follow-up inspection results in all relevant work units. This is under Fitriastuti's (2013) statement which states that the success of an organization is influenced by the individual performance of employees. For this reason, adequate competence is needed from the employees who are responsible for handling this matter. Employees with belowstandard work competencies will not work optimally and can harm the agency because they are the determinants of achieving organizational goals (Simanjuntak, 2015). What is meant by competence are skills, knowledge and understanding, qualities and attributes, a set of values, beliefs, and attitudes that lead to effective managerial performance (Woodall and Winstanley, 1998)? Another definition of competence is based on Government Regulation Number 101 of 2000 concerning Education and Training of Civil Servants (PNS), namely the abilities and characteristics possessed by civil servants, in the form of knowledge, skills, and behavioral attitudes required in carrying out their duties. Research from Makawi, et al. (2015) states that the better the competence, the performance will increase.

Research from Martini et. al. (2018) proves that employee competence shows a positive influence on employee performance. Even among other research variables, competence shows the strongest influence on employee performance. Rantesalu et. al. (2016) in their research also proves that competence has a real influence in increasing organizational commitment and employee performance. The results of these studies support Rifky's (2018) statement which states that the agency's lack of speed and responsiveness in following up on BPK-RI findings could be because the agency does not understand the problem. This implies that if the Ministry of Cooperatives and SMEs want to complete the follow-up to the recommendations on the results of the BPK-RI examination to be effective, it requires employees who have an understanding of the contents of the LHP and related provisions and have adequate skills.

Another factor that affects the follow-up performance of the Ministry of Cooperatives and SMEs is internal control. Internal supervision is carried out by the Inspectorate as a Government Internal Supervisory Apparatus (APIP) under the laws and regulations (Indonesian Government Internal Auditor Association (AAIPI), 2013). Based on the Regulation of the Minister of Cooperatives and SMEs Number 09/Per/M.KUKM/IX/2015 concerning Procedures for Implementing Internal Supervision within the Ministry of Cooperatives and SMEs, internal control is the entire process of auditing, reviewing, evaluating, monitoring, and other supervisory activities against the implementation of organizational tasks and functions to provide adequate assurance that activities have been carried out under established benchmarks effectively and efficiently for the benefit of the leadership in realizing good governance. APIP in carrying out its duties is http://dx.doi.org/10.33642/ijbass.v8n2p 


\title{
International Journal of Business and Applied Social Science
}

\author{
E-ISSN: 2469-6501 \\ VOL: 8, ISSUE: 2 \\ February/2022 \\ DOI: http://dx.doi.org/10.33642/ijbass.v8n2p3 \\ https://creativecommons.org/licenses/by/4.0/
}

obliged to coordinate with, and share information with external auditors and/or other auditors to increase economic value, efficiency, and effectiveness for management (AAIPI, 2013).

Completion of the follow-up to the results of the BPKRI examination is part of the monitoring activities in the Inspectorate's internal supervision task (Arifin, 2017). What is meant by monitoring is the process of assessing the progress of a program/activity in achieving the goals that have been set (AAIPI, 2013). Research from Pongoliu, et al. (2017) stated that support from the Inspectorate was needed to oversee the acceleration of the follow-up completion. With the support from APIP, it is hoped that the completion of follow-up actions will be more timely and under the recommendations provided (Financial and Development Supervisory Agency (BPKP), 2017). Lusiana, et al. (2017) mentions several efforts made by the Inspectorate in accelerating the completion of follow-up, including collecting findings, confirming the implementation of follow-up on inspection results to related work units through warning letters or warrants, as well as inviting related units and third parties to discuss the completion of follow-up inspection results. . These studies confirm that it is necessary to strengthen the internal oversight role of the Inspectorate if the Ministry of Cooperatives and SMEs want the follow-up performance to be effective.

In addition to competence and internal control, another factor that affects the follow-up performance of the Ministry of Cooperatives and SMEs is organizational commitment. Regulation of the Minister of State for the Empowerment of State Apparatus Number 09 of 2009 concerning General Guidelines for Monitoring, Evaluation, and Reporting of Follow-up on the Results of Functional Supervision states that the main obstacle to implementing follow-up on the results of functional supervision is the lack of commitment from the leadership of the Government Agencies that are supervised on the implementation of follow-up on the results of supervision. Organizational commitment is defined by Luthans (2006) as a strong desire to remain a member of a particular organization, a desire to strive according to the wishes of the organization, certain beliefs, and acceptance of the values and goals of the organization. Gibson (1996) defines organizational commitment as the identification of the sense, involvement, loyalty shown by workers to their organization or organizational unit. Employees who have high organizational commitment will have a close sense of connection with their organization which can lead to strong positive behavior towards the organization they have.

Employees will care about the fate of the organization and try to make the organization a better direction. Therefore, management must always try to increase employee awareness to be more attached to the organization (Arijanto and Taufik, 2017). Sapitri's research (2016) proves that organizational commitment has a positive and significant effect on the performance of PLN Pekanbaru Area employees. Meanwhile, Ghoniyah and Masurip (2011) examine employee performance which is influenced by the variables of leadership, work environment, and organizational commitment. The results show that employee performance will be realized if employees in the organization are committed to the organization where they work. These studies imply that employees who have high organizational commitment are needed who are assigned to handle the completion of the follow-up to the results of the BPK-RI examination at the Ministry of Cooperatives and SMEs so that its implementation can run according to the expected results.

In addition, several studies also underline that there is a relationship between competence and internal control on performance through organizational commitment. This relationship shows different results, not only has a significant effect but can have no significant effect or even weaken. Patulak et. al. (2013) stated that directly employee competence does not have a significant effect on performance, but organizational commitment can strengthen the influence between employee competence and performance. In Hastuti's research (2018), it is stated that competence has no significant effect on work commitment, work commitment has a positive effect on performance, and work commitment cannot be an intervening variable for the effect of work competence on performance. Then Sujana's research (2012) found that competence has a significant effect on organizational commitment and organizational commitment has a significant effect on performance, the direction of the influence is positive.

Regarding supervision, Febriani and Suharnomo (2018) state that partial supervision has a positive and significant effect on the organizational commitment variable, and organizational commitment mediates the relationship between supervision and performance. The research results of Nurhawa et. al. (2019) states that supervision does not affect employee commitment. Meanwhile, Yani and Kristanto (2016) state that partially supervision has a significant influence on employee performance, the direction of the influence is positive. However, in moderation, the characteristics of organizational commitment can weaken the influence of supervision on employee performance.

\section{Literature Review}

\section{Follow-up Performance}

Performance has very diverse definitions. According to the Big Indonesian Dictionary, performance means the achievements shown. Robbins and Coulter (2012) state that performance is the result of an activity. Mangkunegara in Sari and Hadijah (2016) defines performance as the result of work in quality and quantity achieved by an employee in carrying out his duties under the responsibilities given to him.

Moeheriono in Makawi, et al. (2015) defines performance as the work that can be achieved by a person or group of people in an organization, both quantitatively and qualitatively, by their respective authorities and responsibilities to achieve the goals of the organization concerned legally, not 
International Journal of Business and Applied Social Science

\author{
E-ISSN: 2469-6501 \\ VOL: 8, ISSUE: 2 \\ February/2022 \\ DOI: http://dx.doi.org/10.33642/ijbass.v8n2p3 \\ https://creativecommons.org/licenses/by/4.0/
}

violating the law, and under with morals and ethics. Another understanding of performance is mentioned by Moeheriono in Syahyuni (2016), which is a description of the level of achievement of the implementation of an activity program or policy in realizing the goals, objectives, vision, and mission of the organization as outlined through the strategic planning of an organization. Meanwhile, according to Torang in Posuma (2013), performance is the quantity or quality of the work of individuals or groups within the organization in carrying out main tasks and functions that are guided by norms, standard operating procedures, criteria, and measures that have been determined or applicable in the organization.

To measure performance, an indicator is needed that can provide information on the extent to which the organization has succeeded in realizing the strategic goals set. Regulation of the Minister of State for Empowerment of State Apparatus Number: PER/09/M.PAN/5/2007 states that in government agencies, this performance measurement is carried out by setting Key Performance Indicators (IKU). In compiling performance indicators, it is better to meet several criteria, including specific, measurable, achievable, relevant and has a time limit. The completion of the follow-up to the results of the BPK-RI examination is one of the Main Performance Indicators at the Ministry of Cooperatives and SMEs in 2021 with a minimum compliance target of $75 \%$ every semester.

Follow-up performance means progress or completion of the findings of the BPK-RI examination (Arifin, 2017). In other words, the follow-up performance is the organization's achievement in implementing the follow-up recommendations submitted by BPK-RI in the report on the results of the examination of BPK-RI. This performance is reflected in the Monitoring Results Report on the Follow-up to the Recommendations on the Audit Results of the BPK-RI issued by the BPK-RI every semester under BPK-RI Regulation Number 1 of 2017 concerning State Auditing Standards. Referring to Mangkunegara (2006), indicators of follow-up performance in this study, namely work quantity and work quality.

\section{Competence}

Competence comes from the word competence, which means ability, authority, and skill. Some experts are quite varied in providing an understanding of competence. Dessler (2011) states that competence is a characteristic shown by a person, including knowledge, skills, and behaviors that lead to effective performance. In government agencies, according to Government Regulation Number 101 of 2000 concerning Education and Training of Civil Servants (PNS), competence is defined as the capabilities and characteristics possessed by civil servants in the form of knowledge, skills, and behavioral attitudes required in carrying out their duties.

McClelland (1973) explains that job success is not only determined by intelligence factors but a group of factors consisting of traits, characteristics, and behaviors called competencies. According to Woodall and Winstanley (1998), competencies are skills, knowledge, understanding, qualities and attributes, a set of values, beliefs, and attitudes that lead to effective managerial performance. Dubois and Rothwell in Rothwell and Kazanas (2003) define competence as the characteristics needed to be able to achieve the desired work results. This includes not only knowledge, skills, and attitudes, but also personality characteristics, levels of motivation, and other factors that differentiate one person from another. This statement is under Putri (2015) who says that competence is a characteristic that underlies a person to perform high in his work in the form of knowledge, skills, and other abilities or personality. So far, the characteristics that are often favored are only knowledge and skills, when in fact behavioral factors (other abilities including values) or a person's personality can also determine success in work.

Another factor forming competence is the attitude which is a way of thinking or what is felt towards something that is reflected in the form of behavior (Marsam in Dahniar, 2019). This attitude has at least three main aspects, namely cognitive, affective and conative. Cognitive aspects are aspects related to thoughts in the form of processing, experience, and beliefs as well as individual expectations about objects. Then, the affective aspect involves certain feelings such as fear, malice, sympathy, antipasti and so on which are aimed at certain objects. Finally, the conative aspect is a process of tendency or tendency to do something about the object. Referring to the view of Dessler (2011), the indicators of competence in this study, namely knowledge, skills, and behavioral attitudes.

\section{Internal Monitoring}

In the public sector (government) environment, the term supervision is often used interchangeably with the term control. Supervision is defined by Robbins and Coulter (2012) as an activity to monitor, compare and improve work results to ensure that the work results are under the goals that have been set. Henry Fayol in Verma, et al. (2013) states that supervision means verifying whether everything is going according to the established plans, rules, and policies that have been made. The goal is to prevent deviations or minimize errors due to violations in the implementation of plans, misunderstandings between planners and implementers, lack of job descriptions, and subordinates who lack mastery of work (Indartono, 2016).

Meanwhile, Revrison in Halidayati (2014) defines internal control as supervision carried out by supervisory officers who come from the internal environment of government organizations. The aim is not only to verify but also to assist the supervised parties to perform their duties better. Internal supervision according to The Institute of Internal Auditors, namely: "an independent, objective assurance, and consulting activity designed to add value and improve an organization's operations. It helps an organization accomplish its objectives by bringing a systematic, disciplined approach to evaluate and improve the effectiveness of risk management, control, and governance processes" (AAIPI, 2018). 


\title{
International Journal of Business and Applied Social Science
}

\author{
E-ISSN: 2469-6501 \\ VOL: 8, ISSUE: 2 \\ February/2022 \\ DOI: http://dx.doi.org/10.33642/ijbass.v8n2p3 \\ (c) (i) \\ https://creativecommons.org/licenses/by/4.0/
}

In practice, internal control activities are divided into activities to provide assurance consisting of audits, reviews, evaluations, and monitoring; and consulting activities consisting of mentoring, coaching clinics, and other educational activities (AAIPI, 2018). Referring to this view, the indicators of internal control in this study are monitoring and mentoring.

\section{Organizational Commitment}

Feldman in Wijaya and Rifa'i (2016) defines commitment as a person's tendency to involve themselves in what is done with the belief that the activities carried out are important and meaningful. Meanwhile, organizational commitment is a sense of unity, bond, and loyalty expressed by individuals towards their organization (Steers in Wijaya and Rifa'i, 2016).

Robbins and Coulter (2012) state that "organizational commitment is the degree to which an employee identifies with a particular organization and its goals and wishes to maintain membership in that organization". According to McShane and Glinow (2010), organizational commitment is the emotional attachment, sense identification, and involvement shown by employees to their organization. Organizational commitment is formed from the daily life of employees in understanding the situation and condition of the organization that arises from a high sense of concern to make significant changes to the physical and non-physical conditions of the organization. This forms a strong mental process that can revive the spirit in the organization by trying to carry out all organizational activities with full perseverance and consistency (Wijaya and Rifa'i, 2016).
Employees who have high organizational commitment will have a close sense of connection with the organization. Employees will see themselves as true members of the organization. This of course can lead to strong positive behavior from employees towards the organization. Employees will have mental and physical readiness to be able to do all the work assigned to them, care about the fate of the organization and try to make the organization a better direction (Gibson, 1996).

This organizational commitment is not only owned by individuals but can also be a group. Employees with organizational commitment will usually have a good attendance record, be loyal to company policies, and have a lower turnover rate (Wibowo, 2017). Therefore, organizational leaders need to give attention and motivation to their employees so that the level of understanding and awareness of employees towards the organization increases so that organizational commitment also increases. Referring to Wijaya and Rifai'i (2016), the indicators of organizational commitment in this study, namely affective commitment, continual commitment, and normative commitment.

\section{Research Methods}

\section{Research Design}

This research is quantitative research using an explanatory research approach. The statistical analysis in this study is descriptive statistics and inferential statistics using path analysis and Sobel tests. For the location of the research conducted on employees of the Ministry of Cooperatives and SMEs. Meanwhile, the time for conducting the research is December 2020-January 2021.

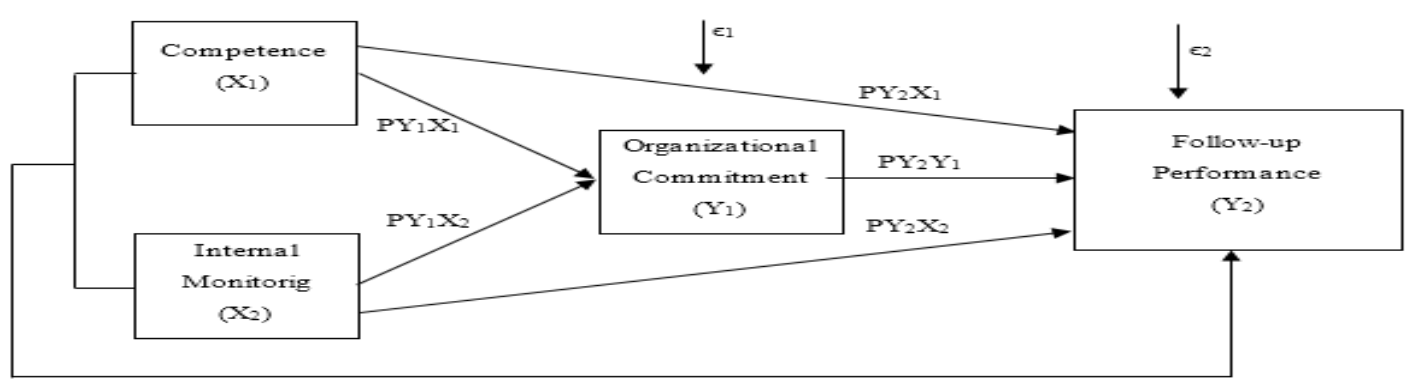

Figure 1. Concept Model

\section{Population and Sample}

The population of this study was all employees who handled the follow-up to the results of the BPK-RI examination at the Ministry of Cooperatives and SMEs, with as many as 180 employees spread across various work units. While the number of samples as many as 125 employees with the sampling technique using the stratified random sampling method.

\section{Data Collection Technique}

The primary data collection technique in this study used a questionnaire in which the respondent chose one condition that best suited him. While secondary data is obtained through publications in the form of an overview of the results of the BPK-RI inspection, reports on the results of follow-up monitoring of the results of the BPK-RI inspections at the Ministry of Cooperatives and SMEs, profiles and organizational structures of the Ministry of Cooperatives and SMEs, relevant laws and regulations, and other publications.

\section{Data Analysis Technique}

Before the analysis, the collected data needs to be processed and tested for quality to ensure that the data can describe the population under study. The data quality test consists of 2 (two) kinds, namely the validity test and the reliability test. Validity tests are carried out to determine how well the instrument measures certain concepts (Sekaran and Bougie, 2016). Meanwhile, the reliability test aims to determine whether the consistency of the measuring instrument is reliable 


\title{
International Journal of Business and Applied Social Science
}

\author{
E-ISSN: 2469-6501 \\ VOL: 8, ISSUE: 2 \\ February/2022 \\ DOI: http://dx.doi.org/10.33642/ijbass.v8n2p3 \\ https://creativecommons.org/licenses/by/4.0/
}

and the results remain consistent if repeated measurements are made.

After testing the quality of the data, before being analyzed with certain techniques (which are classified as parametric statistical tests), the data must also meet the classical assumption test. The classical assumption test is used to determine whether the research data meets the requirements for further analysis to answer the research hypothesis (Gunawan, 2017). Purnomo (2016) states that a linear regression model is called good if it fulfills several classical assumptions, namely the residual data is normally distributed, the absence of multicollinearity, autocorrelation, and heteroscedasticity. Therefore, the classical assumption test used in this study includes the normality test, multicollinearity test, autocorrelation test, and heteroscedasticity test.

\section{Results and Discussion}

\section{1) The direct influence of competence and internal control on organizational commitment}

The magnitude of the R Square (r2) is 0.112 so the magnitude of the influence of competence and internal control on organizational commitment is simultaneously obtained by calculating the coefficient of determination (KD), namely $\mathrm{r} 2 \mathrm{x}$ $100 \%=11.2 \%$. While the rest of $(1-\mathrm{r} 2)=88.8 \%$ is influenced by other factors. In other words, the variability of organizational commitment that can be explained by using the competence and internal control variables is $11.2 \%$ while the effect of $88.8 \%$ is caused by other variables outside this model. The coefficient value $1=\left(1-\mathrm{r}^{\wedge} 2\right)=0.942$.

Testing can be done by comparing the magnitude of the research $\mathrm{F}$ number with the $\mathrm{F}$ table or by comparing the research significance level ( $\mathrm{sig}$ ) with a significance level of 0.05. If the research sig $<0.05$, then there is an effect. Based on the ANOVA table above, the calculation of the significant number is $0.001<0.05$, meaning that there is a significant influence between competence and internal control with organizational commitment. To see the influence between competence and internal control partially on organizational commitment, the T-test is used.

To determine the effect of competence on organizational commitment, it can be done by comparing the magnitude of the research $\mathrm{t}$ figure with the $\mathrm{t}$ table. With a significance level of 0.05 and degrees of freedom $(n-2)=125-$ $2=123$, the t-table number is 1.98 . If the research $\mathrm{t}>\mathrm{t}$ table, then there is an effect. Based on table 22 above, it can be seen that the research $\mathrm{t}$ figure is $0.173<\mathrm{t}$ table 1.98 , so $\mathrm{H} 0$ is accepted and $\mathrm{H} 1$ is rejected. This means that there is no influence between competence on organizational commitment. The magnitude of the influence of competence on organizational commitment is 0.019 or $1.9 \%$ so it is considered insignificant. This is reflected in the significant figure of 0.863 which is greater than 0.05. Every time there is an increase in incompetence, it will only affect the increase in the organizational commitment by 0.019 .
To determine the effect of internal control on organizational commitment, it can be done by comparing the magnitude of the research $t$ number with the $t$ table. With a significance level of 0.05 and degrees of freedom $(n-2)=125$ $2=123$, the $\mathrm{t}$-table number is 1.98 . If the research $\mathrm{t}>\mathrm{t}$ table, then there is an effect. Based on table 22 above, it can be seen that the magnitude of the research $t$ number is $2.849>t$ table 1.98, then $\mathrm{H} 0$ is rejected and $\mathrm{H} 1$ is accepted. This means that there is an influence between internal control on organizational commitment. The magnitude of the influence of internal control on organizational commitment is 0.322 or $32.2 \%$ and is significant. This is reflected in the significant figure of 0.005 which is smaller than 0.05 . Every time there is an increase in internal control, it will affect the increase in the organizational commitment by 0.322 .

\section{2) The direct influence of competence, internal control, and organizational commitment on follow-up performance \\ To determine the effect of competence, internal} control, and organizational commitment simultaneously on the follow-up performance. The magnitude of the R Square (r2) is 0.482 so that the magnitude of the influence of competence, internal control, and organizational commitment simultaneously on the follow-up performance is obtained by calculating the coefficient of determination (KD), namely $\mathrm{r} 2 \times 100 \%=48.2 \%$ While the rest of $(1-\mathrm{r} 2)=51.8 \%$ is influenced by other factors. In other words, the variability of follow-up performance that can be explained by using the variables of competence, internal control, and organizational commitment is $48.2 \%$ while the effect of $51.8 \%$ is caused by other variables outside this model. The coefficient value $2=\left(1-r^{\wedge} 2\right)=0.720$.

Testing can be done by comparing the magnitude of the research $\mathrm{F}$ number with the $\mathrm{F}$ table or by comparing the research significance level ( $\mathrm{sig}$ ) with a significance level of 0.05. If the research sig $<0.05$, then there is an effect. Based on the ANOVA table above, the calculation of the significant number is $0.000<0.05$, meaning that there is an influence between competence, internal control, and organizational commitment on follow-up performance.

To determine the effect of competence on follow-up performance, it can be done by comparing the magnitude of the research $t$ number with the $t$ table. With a significance level of 0.05 and degrees of freedom $(n-2)=125-2=123$, the magnitude of the $\mathrm{t}$ table number is 1.98 . If the research $\mathrm{t}>\mathrm{t}$ table, then there is an effect. Based on table 25 above, it can be seen that the magnitude of the research $\mathrm{t}$ number is $4.154>\mathrm{t}$ table 1.98, meaning that there is an influence between competence on follow-up performance. The magnitude of the influence of competence on the follow-up performance is 0.36 or $36 \%$ and is significant. This is reflected in the significant figure of 0.00 which is smaller than 0.05 . Every time there is increased incompetence, it will affect the increase in follow-up performance by 0.36 .

To find out the effect between internal control and follow-up performance, it can be done by comparing the 


\title{
International Journal of Business and Applied Social Science
}

\author{
E-ISSN: 2469-6501 \\ VOL: 8, ISSUE: 2 \\ February/2022 \\ DOI: http://dx.doi.org/10.33642/ijbass.v8n2p3 \\ (c) (i) \\ https://creativecommons.org/licenses/by/4.0/
}

magnitude of the research $\mathrm{t}$ number with the $\mathrm{t}$ table. With a magnitude of the research $\mathrm{t}$ number with the $\mathrm{t}$ table. With a significance level of 0.05 and degrees of freedom $(n-2)=125-$ significance level of 0.05 and degrees of freedom $(n-2)=125-$ $2=123$, the $\mathrm{t}$-table number is 1.98 . If the research $\mathrm{t}>\mathrm{t}$ table, $2=123$, the $\mathrm{t}$-table number is 1.98 . If the research $\mathrm{t}>\mathrm{t}$ table, then there is an effect. Based on table 25 above, it can be seen then there is an effect. Based on table 25 above, it can be seen that the magnitude of the research $t$ number is $2.527>\mathrm{t}$ table 1.98, meaning that there is an influence between internal control and follow-up performance. The magnitude of the influence of internal control on the follow-up performance is 0.226 or $22.6 \%$ and is significant. This is reflected in the significant figure of 0.013 which is smaller than 0.05 . Every time there is an increase in internal control, it will affect the increase in follow-up performance by 0.226 .

To determine the effect of organizational commitment that the magnitude of the research $t$ number is $4.488>\mathrm{t}$ table 1.98 , meaning that there is an influence between organizational commitment and follow-up performance. The magnitude of the effect of organizational commitment on follow-up performance is 0.312 or $31.2 \%$ and is significant. This is reflected in a significant figure of 0.000 which is smaller than 0.05 . Every time there is an increase in organizational commitment, it will affect the increase in follow-up performance by 0.312 .

\section{3) Path Diagram Model Results}

with follow-up performance, it can be done by comparing the

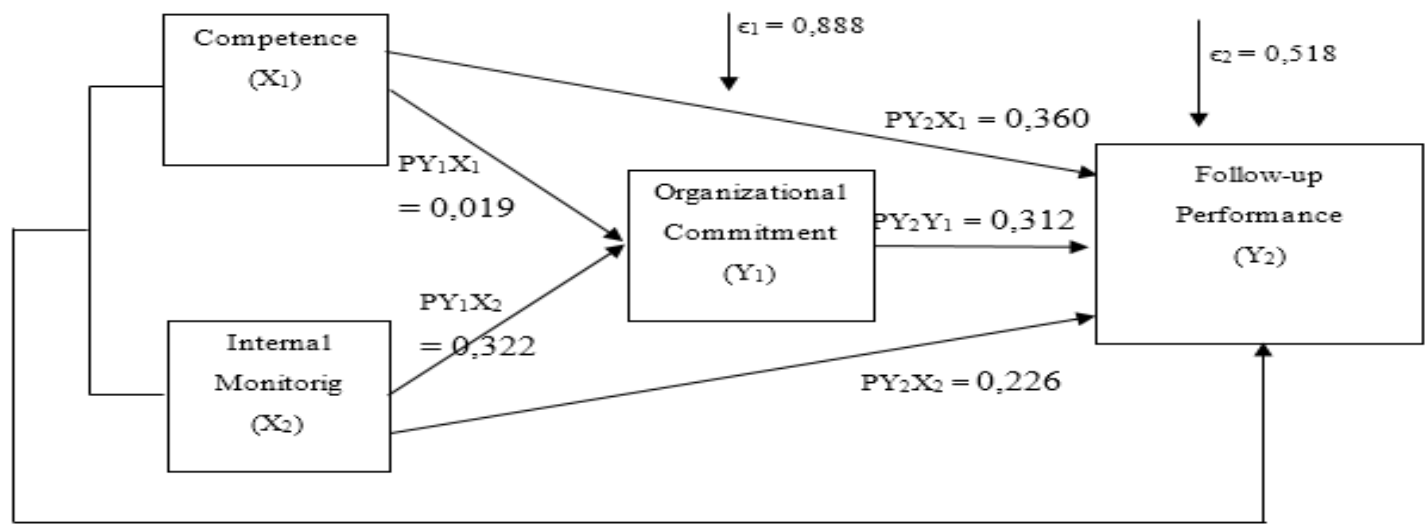

Figure 2. Results of the Path Diagram Model

Based on the results of the research model above, the structural equation can be described as follows:

Substructure equation 1: Y_1=0.019 X_1+ $0.322 \mathrm{X} \_2+$ _1

Substructure equation 2: $\mathrm{Y}_{-} 2=0,360 \mathrm{X}_{-} 1+0,312 \mathrm{Y}_{-} 1+0,226$ X_2+_2

\section{Sobel Test}

Based on the results of the path analysis, it can be seen that the organizational commitment variable meets the criteria to be tested as a mediator variable because:
- In the equation, the independent variable (X) namely competence and internal control affects the dependent variable (Y), namely the follow-up performance;

- In the equation, the independent variable (X) namely competence and internal control affects the mediator variable $(\mathrm{M})$, namely organizational commitment;

- In the equation, the mediating variable (M), namely organizational commitment, affects the dependent variable (Y), namely the follow-up performance.

1. Effect of Competence (X1) on Follow-up Performance (Y2) through Organizational Commitment (Y1)

\begin{tabular}{|c|c|c|c|c|c|}
\hline & Input: & & Test statistic: & Std. Error: & $p$-value: \\
\hline$a$ & 0.021 & Sobel test: & 0.17200635 & 0.03088839 & 0.86343254 \\
\hline$b$ & 0.253 & Aroian test: & 0.16794724 & 0.03163494 & 0.86662479 \\
\hline$s_{\mathrm{a}}$ & 0.122 & Goodman test: & 0.17637476 & 0.03012336 & 0.85999953 \\
\hline & 0.056 & Reset all & & Calculate & \\
\hline
\end{tabular}

Figure 3. Sobel Competency Test Results

For $=0.05(5 \%)$, the value of $\mathrm{z}$-table is 1.96 . If $\mathrm{Z}$ - the significance value (p-value) $=0.86$ which is greater than count Z-table, then there is an effect. Based on the picture 0.05 which means it is not significant. Thus, organizational above, it can be seen that $\mathrm{z}$-count $=0.172$. Because $\mathrm{z}$-count $<$ commitment does not mediate the influence between z-table, it means that there is no influence between competence and follow-up performance.

Competence (X1) on Follow-up Performance (Y2) through 2. The Effect of Internal Control (X2) on Follow-Up Organizational Commitment (Y1). This can also be seen from Performance (Y2) through Organizational Commitment (Y1) 


\title{
International Journal of Business and Applied Social Science
}

\author{
E-ISSN: 2469-6501 \\ VOL: 8, ISSUE: 2 \\ February/2022 \\ DOI: http://dx.doi.org/10.33642/ijbass.v8n2p3 \\ (c) (7) \\ https://creativecommons.org/licenses/by/4.0/
}

\begin{tabular}{|c|c|c|c|c|}
\hline Input: & & Test statistic: & Std. Error: & $p$-value: \\
\hline a 0.339 & Sobel test: & 2.40969529 & 0.03559247 & 0.01596585 \\
\hline$b \quad 0.253$ & Aroian test: & 2.36853796 & 0.03621095 & 0.01785855 \\
\hline $\begin{array}{ll}s_{\mathrm{a}} & 0.119\end{array}$ & Goodman test: & 2.45307552 & 0.03496305 & 0.01416406 \\
\hline \begin{tabular}{l|l}
$s_{\mathrm{b}}$ & 0.056
\end{tabular} & Reset all & & Calculate & \\
\hline
\end{tabular}

Figure 4. Sobel Test Results of Internal Control

For $=0.05(5 \%)$, the value of z-table is 1.96 . If $\mathrm{Z}$ count Z-table, then there is an effect. Based on the picture above, it can be seen that $\mathrm{z}$-count $=2.41$. Because $\mathrm{z}$-count $>\mathrm{z}$ table, it means that there is an influence between Internal Control (X2) on Follow-up Performance (Y2) through Organizational Commitment (Y1). This can also be seen from the significance value $(\mathrm{p}$-value $)=0.016$ which is smaller than 0.05 which means significant. Thus, organizational commitment mediates the influence between internal control and follow-up performance.

\section{DISCUSSION}

Competence is a characteristic possessed by a person, including knowledge, skills, and behavioral attitudes needed in the context of carrying out his work duties and responsibilities. The indicators of competence in this study were adopted from Dessler (2011), namely knowledge, skills, and behavioral attitudes.

Based on the results of the descriptive analysis, it is known that the behavioral attitude indicators provide the greatest support for the formation of employee competencies at the Ministry of Cooperatives and SMEs. This is reflected in the attitude of employees who always seek to find out the performance achievements of the follow-up to the results of the BPK-RI examination in the monitoring results report every semester, are present on time at work, can accept criticism/input from superiors, and co-workers well, and always carry out work according to with applicable regulations. Meanwhile, the knowledge indicator provides the lowest support for the formation of employee competencies at the Ministry of Cooperatives and SMEs. This relates to the understanding of the employee's work objectives in completing follow-up actions, knowledge in completing follow-up actions, and understanding the rules relating to examination findings and follow-up completion procedures.

Next, internal control is an assurance and consulting activity carried out to increase organizational value and realize good governance. The indicators of internal control in this study were adopted from AAIPI (2018), namely monitoring as a form of guarantee activities and mentoring as a form of consulting activities.

Based on the results of descriptive analysis, it is known that the mentoring indicator provides the greatest support for the establishment of internal control at the Ministry of Cooperatives and SMEs. This is reflected in the role of the Inspectorate which carries out an adequate communication process to ensure that the responsible work unit has understood the findings and recommendations of the BPK-RI examination results, provides appropriate direction/input related to efforts to complete follow-up inspection results to the responsible work unit, assists the work unit. the person in charge coordinates with third parties when there are difficulties verifies the follow-up document on the results of the BPK-RI examination from the responsible work unit to be reported to BPK-RI, and bridges communication with the BPK-RI Team regarding the implementation of the follow-up to the results of the BPK-RI examination well. Meanwhile, the monitoring indicators provide the lowest support for the establishment of internal control at the Ministry of Cooperatives and SMEs. This relates to the submission of inspection reports and followup monitoring reports to the responsible work unit regularly, giving time limits to the responsible work unit to follow up on findings and recommendations from BPK-RI examination results, monitoring the progress of follow-up completion by facilitating periodic meetings and informal means with the responsible work unit, submitting follow-up documents from the responsible work unit to the BPK-RI accordingly, and imposing sanctions on the responsible work unit if they do not follow up on the results of the BPK-RI examination.

Then, organizational commitment is a sense of attachment that an employee has to his organization which gives rise to an urge to behave positively for the sake of his organization. The indicators of organizational commitment in this study were adopted from Wijaya and Rifai (2016), namely affective commitment, continual commitment, and normative commitment.

Based on the results of the descriptive analysis, it is known that the normative commitment indicator provides the greatest support for the formation of organizational commitment at the Ministry of Cooperatives and SMEs. This is reflected in the views of employees who agree that it is unethical to move from one organization to another, the importance of loyalty, the importance of loyalty to the organization, including reluctance to leave the organization despite getting a better job offer outside. Meanwhile, the sustainability commitment indicator provides the lowest support for the formation of organizational commitment at the Ministry of Cooperatives and SMEs. This relates to employee considerations regarding the need to continue working in the organization, the choices they have when leaving the organization, and the advantages/disadvantages of leaving the organization. 


\title{
International Journal of Business and Applied Social Science
}

\author{
E-ISSN: 2469-6501 \\ VOL: 8, ISSUE: 2 \\ February/2022 \\ DOI: http://dx.doi.org/10.33642/ijbass.v8n2p3 \\ https://creativecommons.org/licenses/by/4.0/
}

Finally, follow-up performance is an achievement or work achievement in following up or completing recommendations on examination results from BPK-RI. Indicators of follow-up performance in this study were adopted from Mangkunegara (2006), namely work quantity and work quality.

Based on the results of descriptive analysis, it is known that the indicators of work quality provide the greatest support for the formation of follow-up performance at the Ministry of Cooperatives and SMEs. This is reflected in the ability of employees to complete work with a minimum error rate, responsibility for the work done, the results of employee work can be understood by superiors and colleagues, trying to maintain the good name of the organization is doing work, and administering work in an orderly manner. Meanwhile, the work quantity indicator provides the lowest support for the formation of follow-up performance at the Ministry of Cooperatives and SMEs. This relates to the ability of employees to complete follow-up to the results of the BPK-RI examination according to the specified time, not to do other things that are not related to the main tasks and functions during working hours, to immediately complete the work assigned (not to delay until the end of the completion deadline), keep coming to work even though there is no work to be done, and the willingness to do additional tasks given.

\section{The Influence of Competence and Internal Control on} Organizational Commitment at the Ministry of Cooperatives and SMEs

Based on the results of the path analysis, it is known that competence and internal control provide significant support for increasing organizational commitment at the Ministry of Cooperatives and SMEs. Increased competence and internal control together will lead to an increase in organizational commitment. The results of this study are in line with research conducted by Aprilia (2019) which shows that supervision, work environment, and competence simultaneously have a positive effect on organizational commitment.

\section{The Influence of Competence on Organizational} Commitment at the Ministry of Cooperatives and SMES

Based on the results of the path analysis, it is known that competence supports the increase in organizational commitment at the Ministry of Cooperatives and SMEs, but not significantly so that it can be said to have no effect. Competence is not a determining factor for organizational commitment. Partially increasing employee competence will not lead to an increase in organizational commitment. Or in other words, organizational commitment can be realized regardless of competence. Organizational commitment is formed from other factors that have a significant influence.

The results of this study are inversely proportional to the results of research by Sujana (2012), Patulak et. al. (2013), Rantesalu et. al. (2016), Yamali (2017), and Aprilia (2019) which show that there is a positive and significant influence between employee competence and organizational commitment. High employee competence will increase employee commitment to the organization. However, this study shows the same results as research conducted by Hastuti (2018) which states that competence does not affect work commitment. Competence is not a factor that forms work commitment.

\section{The Effect of Internal Control on Organizational} Commitment at the Ministry of Cooperatives and SMEs

Based on the results of the path analysis, it is known that internal control significantly increases organizational commitment at the Ministry of Cooperatives and SMEs. Internal control is one of the factors that shape organizational commitment. A partial increase in internal control will lead to an increase in organizational commitment. Or in other words, organizational commitment can be realized with high internal control. Internal control affects organizational commitment because the evaluation, guidance, direction obtained by employees from the internal control process makes employees feel that what they are doing is important and can bring improvements to themselves and the organization. Employees also feel considered and cared for by the organization so it encourages the emergence of employee commitment to their organization which in the end makes employees always try to do their best in their work for their organization.

The results of this study are inversely proportional to the results of research by Aprilia (2019) and Nurhawa et. al. (2019) which states that supervision does not affect commitment. However, this is under the results of research by Febriani and Suharnomo (2018) which showed that partial supervision had a positive and significant effect on organizational commitment. The higher the supervision carried out by the company for its employees, the higher the employee's commitment to the organization. And vice versa, if there is a lack of supervision provided by the company to its employees, the organizational commitment will also decrease.

6. The Influence of Competence, Internal Supervision, and Organizational Commitment on Follow-Up Performance at the Ministry of Cooperatives and SMEs

Based on the results of the path analysis, it is known that competence, internal control, and organizational commitment provide significant support for increasing followup performance at the Ministry of Cooperatives and SMEs. Increasing competence, internal control, and organizational commitment together, will encourage increased follow-up performance. The results of this study are in line with research conducted by Aprilia (2019) which shows that supervision, work environment, competence, and organizational commitment simultaneously have a positive effect on performance.

7. The Effect of Competence on Follow-up Performance at the Ministry of Cooperatives and SMEs

Based on the results of the path analysis, it is known that competence significantly supports the improvement of 


\title{
International Journal of Business and Applied Social Science
}

\author{
E-ISSN: 2469-6501 \\ VOL: 8, ISSUE: 2 \\ February/2022 \\ DOI: http://dx.doi.org/10.33642/ijbass.v8n2p3 \\ https://creativecommons.org/licenses/by/4.0/
}

follow-up performance at the Ministry of Cooperatives and SMEs. One of the follow-up performances is determined by the employee's competence. An increase in employee competence will partially lead to an increase in follow-up performance. The better the competence of employees, the better their performance in completing the follow-up to the results of the BPK-RI examination. On the other hand, the lower the competency of the employee, the lower the performance in completing the follow-up to the results of the BPK-RI examination. Competence can affect performance because employees who have high competence have the knowledge, skills, and behavioral attitudes needed to produce good work. The employee understands the goals to be achieved from his work and always strives to improve selfquality which in turn can improve performance.

The results of this study are inversely proportional to the results of research by Patulak et. al. (2013) and Aprilia (2019) which state that competence does not affect performance. However, this is under the results of the Cultural Research (2019) which states that the lack of HR competence is a factor that makes it difficult to complete the follow-up to the results of the BPK-RI examination. In addition, research by Sujana (2012), Wardhana et. al. (2015), Rantesalu et. al. (2016), Yamali (2017), Hastuti (2018), Kawiana et. al. (2018), Martini et. al. (2018), and Irvan (2019) also mention that competence partially has a significant effect on employee performance.

\section{The Effect of Internal Supervision on Follow-Up Performance at the Ministry of Cooperatives and SMEs}

Based on the results of the path analysis, it is known that internal control provides significant support for increasing follow-up performance at the Ministry of Cooperatives and SMEs. Internal control is one of the factors that shape the follow-up performance. Partially increased internal control will improve follow-up performance. The higher the internal control, the better the follow-up performance will be. On the other hand, the lower the internal control, the lower the followup performance. Internal supervision can affect follow-up performance because monitoring and assistance activities carried out in the supervision process can prevent deviations, misunderstandings or minimize errors in the implementation of work. In other words, internal control ensures that the work is carried out as planned and helps the supervised party to carry out their duties better to improve performance.

The results of this study are inversely proportional to the results of research by Rantelangi et. al. (2017) and Aprilia (2019) which state that internal control has a negative and insignificant effect on performance and research by Sahusilawane (2020) which states that internal control does not affect organizational performance. However, this is under the results of Arifin's research (2017) which states that monitoring activities have a positive effect on the completion of the follow-up to the recommendations of the BPK examination findings. In addition, research by Yani and Kristanto (2016),
Nurhawa et. al. (2019), and Lee and Kusumah (2020) also mention that supervision has a positive influence on performance.

\section{The Effect of Organizational Commitment on Follow-Up Performance at the Ministry of Cooperatives and SMEs}

Based on the results of the path analysis, it is known that organizational commitment encourages a significant increase in follow-up performance at the Ministry of Cooperatives and SMEs. Organizational commitment is one of the factors that determine follow-up performance. An increase in organizational commitment will partially lead to an increase in follow-up performance. The higher the organizational commitment, the follow-up performance will also be high. On the other hand, the lower the organizational commitment, the lower the follow-up performance. Organizational commitment can affect performance because employees who have high organizational commitment will have an emotional attachment to their organization, accept the values and goals of the organization and try hard according to the wishes of the organization. This of course can lead to strong positive behavior from employees towards the organization. The employee will always show involvement in his organization and try to make the organization a better direction which ultimately encourages increased performance.

The results of this study are inversely proportional to the results of Sahusilawane's (2020) research which states that organizational commitment does not affect performance. However, this is under research conducted by Lusiana et. al. (2017) and Putera (2019) which stated that the lack of organizational commitment was one of the obstacles in following up on the results of the BPK-RI examination. The results of this study are also the same as the research conducted by Sujana (2012), Patulak et. al. (2013), Yamali (2017), Rantelangi et. al. (2017), Febriani and Suharmono (2018), Kawiana et. al. (2018), Hastuti (2018), Aprilia (2019), and Nurhawa et. al. (2019) which states that organizational commitment has a significant influence on performance.

10. The Effect of Competence on the Follow-up Performance of the Ministry of Cooperatives and SMEs through Organizational Commitment

Based on the results of the path analysis, it is known that organizational commitment is not an intervening variable that mediates the relationship between competence and followup performance at the Ministry of Cooperatives and SMEs. Organizational commitment is only a moderating variable that strengthens the support provided by competence for a followup performance.

This can also be seen from the results of the Sobel Test which shows that there is no influence between competence on follow-up performance through organizational commitment. This means that in this study, organizational commitment is not a mediator in the relationship between competence and follow-up performance. Organizational commitment does not 


\title{
International Journal of Business and Applied Social Science
}

\author{
E-ISSN: 2469-6501 \\ VOL: 8, ISSUE: 2 \\ February/2022 \\ DOI: http://dx.doi.org/10.33642/ijbass.v8n2p3 \\ (c) (i) \\ https://creativecommons.org/licenses/by/4.0/
}

mediate the relationship between competence and follow-up performance.

The results of this study are inversely proportional to the results of research by Rantesalu et. al. (2016) which shows that organizational commitment mediates the relationship between competence and performance and the results of Yamali's research (2017) which states that organizational commitment partially mediates the effect of competence on performance. However, this is under the results of research by Patulak et. al. (2013) and Hastuti (2018) which states that commitment does not mediate the effect of competence on performance (not as an intervening variable).

\section{The Effect of Internal Supervision on the Follow-up Performance of the Ministry of Cooperatives and SMEs} through Organizational Commitment

Based on the results of the path analysis, it is known that organizational commitment is not an intervening variable that mediates the relationship between internal control and follow-up performance. However, the results of the Sobel Test show that there is an influence between internal control and follow-up performance through organizational commitment. Organizational commitment can mediate the effect of internal control on the follow-up performance significantly.

Based on the results of the path analysis and the Sobel test, it can be concluded that organizational commitment partially mediates the relationship between internal control and follow-up performance. This is because before including the organizational commitment variable, the effect of competence on the follow-up performance was significant and after including the organizational commitment variable, the effect remained significant. Thus, organizational commitment is expressed as a partial mediation variable.

The results of this study are different from the results of research by Yani and Kristanto (2016) which states that organizational commitment weakens the influence of supervision on performance. However, this is under the results of research by Febriani and Suharmono (2018) and Nurhawa et. al. (2019) which shows that organizational commitment mediates the relationship between internal control and performance.

\section{Conclusions and Recommendations}

\section{Conclusion}

a. Competence and internal control together provide significant support for increasing organizational commitment at the Ministry of Cooperatives and SMEs.

b. Competence supports the increase in organizational commitment at the Ministry of Cooperatives and SMEs, but not significantly so that it can be said to have no effect.

c. Internal supervision encourages a significant increase in organizational commitment to the Ministry of Cooperatives and SMEs. d. Competence, internal control, and organizational commitment together provide significant support for increasing follow-up performance at the Ministry of Cooperatives and SMEs.

e. Competence supports the improvement of follow-up performance at the Ministry of Cooperatives and SMEs significantly.

f. Internal supervision provides significant support for the improvement of follow-up performance at the Ministry of Cooperatives and SMEs.

g. Organizational commitment has led to a significant increase in follow-up performance at the Ministry of Cooperatives and SMEs.

h. Organizational commitment does not mediate the relationship between competence and follow-up performance.

i. Organizational commitment mediates partial (partial mediation) the relationship between internal control and follow-up performance.

\section{Suggestion}

This research is expected to be used as input and reference for the Ministry of Cooperatives and SMEs to take policies or decisions that are deemed necessary to improve follow-up performance.

\section{a. Follow-up performance}

The Ministry of Cooperatives and SMEs need to pay attention to the work quantity indicator which gives the lowest value to the formation of follow-up performance, especially by reducing things that can interfere with the employee's focus in achieving their work targets, for example by not providing work outside the main duties and functions of the employee and not charging an employee. work for certain employees only because this will make the distribution of work uneven and the available human resources are not optimized properly,

\section{b. Competence}

The Ministry of Cooperatives and SMEs need to pay attention to the knowledge indicator that gives the lowest score for competency formation, especially related to employee understanding of the rules relating to the completion of followup to the results of the BPK-RI examination, for example by frequently holding regular meetings to discuss the obstacles experienced or socializing the latest policies and progress in completing the follow-up to the results of the BPK-RI examination so that all employees have the same knowledge in completing the follow-up to the results of the BPK-RI examination.

\section{c. Internal monitoring}

The Ministry of Cooperatives and SMEs need to pay attention to the monitoring indicators that give the lowest score to the establishment of internal control, especially regarding the imposition of sanctions on the responsible work unit if they do not follow up on the results of the BPK-RI examination. If previously the sanction was only in the form of a written warning, it is necessary to seek more concrete sanctions to 


\title{
International Journal of Business and Applied Social Science
}

\author{
E-ISSN: 2469-6501 \\ VOL: 8, ISSUE: 2 \\ February/2022 \\ DOI: http://dx.doi.org/10.33642/ijbass.v8n2p3 \\ (c) (i) \\ https://creativecommons.org/licenses/by/4.0/
}

provide a deterrent effect to encourage the acceleration of the completion of the follow-up to the results of the examination.

d. Organizational commitment

The Ministry of Cooperatives and SMEs need to pay attention to the indicators of sustainable commitment that give the lowest score for the formation of organizational commitment, especially related to employee engagement with calculative organizations. Things that can be done by the Ministry of Cooperatives and SMEs to increase organizational commitment, include frequently motivating employees, encouraging employee involvement in the organization, routinely internalizing organizational values and goals so that employees understand the organization, and encouraging the growth of awareness within employees to feel emotionally attached with the organization.

\section{Research Limitations}

During the research, there are several limitations experienced by researchers that need to be considered for the perfection of future research, including:

a. Researchers collected primary data using questionnaires distributed online via google form to respondents. This can cause differences in the perceptions of respondents in understanding the meaning of the statements in the questionnaire. In addition, the researcher also did not know whether the respondents were in good condition to answer the questionnaire. As a result, the information provided by respondents from the questionnaire may not reflect the actual conditions.

b. Science is developing so fast, the indicators used by researchers in describing research variables may experience development and may not have been investigated in this study so it needs to be adjusted in subsequent studies to be able to describe the actual conditions.

c. For other researchers who want to examine more deeply follow-up performance, they can develop variables other than competence, internal control, and organizational commitment to obtain new findings because there are still other variables that have not been studied in this study that affect the research model.

\section{References}

Akbar, B.A. 2017. Factors Affecting the Level of Completion of Follow-up to Recommendations on BPK Examination Results in Provincial Governments in Indonesia. Scientific Journal of FEB Students, Universitas Brawijaya, 5(1). Available at: https://jimfeb.ub.ac.id/index.php/jimfeb/article/view/3625/0

Amyulianthy, R., Anto, A.S.U., \& Budi, S. 2020. Findings and Follow-up on Audit Results (Studies on Provincial Governments in Indonesia). Journal of Accounting Research, 1(1), pp.14-27. Available at :

https://scholar.google.co.id/citations?view_op=view_citation\&hl=en\&user=PL56K70AAAAJ\&citation_for_view=PL56K 70AAAAJ:_FxGoFyzp5QC

Aprilia, Juwita. The Effect of Supervision and Work Environment and Competence on Organizational Commitment and Performance on Employees of the Finance Section of the Regent's Office of East Kutai Regency. Management \& Accounting Scientific Research Festival, 2(19), pp.52-64. Available at: http://prosidingfrima.stembi.ac.id/index.php/prosidingfrima/article/view/17

Arifin, Bustanul. 2017. Factors Influencing the Completion of Follow Up on Recommendations for BPK Audit Findings in the Ministry of Finance. Essay. Faculty of Economics and Business. Hasanuddin University Makassar.

Arijanto, A., \& Taufik, M. 2017. Analysis of Effect of Organizational Culture and Organizational Commitment to Performance of PT Aisan Nasmoco Industry Employees. European Journal of Business and Management, 9(3), pp.111-117. Available at : https://core.ac.uk/download/pdf/234627702.pdf

Asbari, Masduki, et. al. 2020. Hard Skills or Soft Skills: Which Is More Important For Teacher Innovation?. Edumaspul - Journal of Education, 4(1), pp. 1-20. Available at: https://ummaspul.e-journal.id/maspuljr/article/view/333/162

Indonesian Government Internal Auditor Association. 2018. Conceptual Framework for Indonesian Government Internal Control. Jakarta: AAIPI.

2013. Indonesian Government Internal Audit Standards. Jakarta: AAIPI.

BPK, 2021. Minutes of Discussion on Follow-up on Examination Results (TLHP) of the Ministry of Cooperatives and Small and Medium Enterprises. Jakarta: Supreme Audit Agency.

2021. Summary of Examination Results for Semester II of 2020. Jakarta: Supreme Audit Agency.

2021. Monitoring Result Report on the Follow-up to the Recommendation of the Second Semester of 2020

BPK-RI Examination Results. Jakarta: Supreme Audit Agency. 


\title{
International Journal of Business and Applied Social Science
}

\author{
E-ISSN: 2469-6501 \\ VOL: 8, ISSUE: 2 \\ February/2022 \\ DOI: http://dx.doi.org/10.33642/ijbass.v8n2p3 \\ (c) (7) \\ https://creativecommons.org/licenses/by/4.0/
}

2020. Summary of First Semester Examination Results 2020. Jakarta: Supreme Audit Agency.

2020. Monitoring Result Report on the Follow-up to the Recommendation of the First Semester of the

Examination of the BPK-RI in 2020. Jakarta: Supreme Audit Agency.

2020. Summary of Examination Results for Semester II of 2019. Jakarta: Supreme Audit Agency.

2020. Monitoring Result Report on the Follow-up to the Recommendation of the Second Semester of 2019

BPK-RI Examination Results. Jakarta: Supreme Audit Agency.

2019. Summary of Examination Results of Semester I of 2019. Jakarta: Supreme Audit Agency.

2019. Monitoring Result Report on the Follow-up to the Recommendation of BPK-RI Examination Results for Semester I of 2019. Jakarta: Supreme Audit Agency.

2019. Summary of Semester II 2018 Examination Results. Jakarta: Supreme Audit Agency.

2019. Monitoring Result Report on the Follow-up to the Recommendation of the Second Semester of 2018

BPK-RI Examination Results. Jakarta: Supreme Audit Agency.

2018. Summary of Examination Results of Semester I of 2018. Jakarta: Supreme Audit Agency.

2018. Report on Monitoring Results on Follow-up to Recommendations on Examination Results of BPK-RI

Semester I of 2018. Jakarta: Supreme Audit Agency.

2018. Summary of Examination Results for Semester II of 2017. Jakarta: Supreme Audit Agency.

2018. Report on Monitoring Results on Follow-up to Recommendations on Examination Results of BPK-RI

Semester II of 2017. Jakarta: Supreme Audit Agency.

-----. 2017. Summary of Examination Results of Semester I of 2017. Jakarta: Supreme Audit Agency.

2017. Monitoring Result Report on the Follow-up to the Recommendation of BPK-RI Examination Results for Semester I of 2017. Jakarta: Supreme Audit Agency.

2016. BPK Targets 75\% Institutional Compliance. Jakarta. [on line]

http://www.bpk.go.id/news/bpk-targetkan-kepatuhan-instansi-75 [diakses 15 September 2018]

Financial and Development Supervisory Agency. 2017. The role of APIP in the Acceleration of Follow-up on Examination Results, North Maluku. [on line]

http://www.bpkp.go.id/malut/berita/read/19077/0/Peran-APIP-dalam-Percepatan-Tindak-Lanjut-Hasil-

Pemeriksaan.bpkp [accessed March 27, 2020]

Baihaqi. 2016. Supervision as a Function of Library Management and Its Relationship with Librarian Discipline.

LIBRA, 8(1), pp.129-142. Available at : http://103.107.187.25/index.php/libria/article/view/1227

Culture, Arif. 2019. Analysis of the Completion of Follow-Up on the Recommendations of the Audit Results of the Supreme Audit Agency of the Republic of Indonesia on the Regional Owned Enterprises Supervisory Unit (Case Study on the Yogyakarta City Government BUMD Guiding Unit 2016). Accounting and Business Information Systems Journal, 7(4). Available at: https://journal.ugm.ac.id/abis/article/view/58797

Dahniar, Ati. 2019. Understanding the Formation of Attitudes in Education and Training. Journal of the Bandung Religious Education and Training Center, 13(2), pp.202-206. Available at:

https://media.neliti.com/media/publications/299549-memahami-pemunjukan-sikap-attitude-dala-31cf5e3b.pdf

Dessler, Gary. 2011. Human Resource Management (12th ed.). New Jersey: Pearson.

Duwi Consultant. 2011. Questionnaire Reliability Test. [on line] http://duwiconsultant.blogspot.com/2011/11/ujireliabilitas-kuisioner.html [accessed September 25, 2018]

Essing, S.A., Saerang, D.P.E., \& Lambey, L. 2017. Analysis of the Follow-up Implementation of BPK RI's Audit Results on Local Government Financial Reports in Talaud Islands Regency. Journal of Accounting and Auditing Research "Goodwill", 8(1), pp.118-128. Available at:

https://ejournal.unsrat.ac.id/index.php/goodwill/article/view/15331

Febriani, D.S.H., \& Suharnomo. 2018. The Effect of Supervision, Work Motivation, and Interpersonal Communication on Employee Performance with Organizational Commitment as an Intervening Variable (Study at PT. Pos Indonesia (Persero) Ungaran Branch). Diponegoro Journal of Management, 7(1). Available at: https://ejournal3.undip.ac.id/index.php/djom/article/view/20895 


\title{
International Journal of Business and Applied Social Science
}

\author{
E-ISSN: 2469-6501 \\ VOL: 8, ISSUE: 2 \\ February/2022 \\ DOI: http://dx.doi.org/10.33642/ijbass.v8n2p3 \\ (c) (i) \\ https://creativecommons.org/licenses/by/4.0/
}

Fernandez, I.B., \& Sabherwal, R. 2010. Knowledge Management: Systems and Processes (1st ed.). New York: M.E. Sharpe

Firmansyah, A., \& Mahardhika, B.W. 2018. Introduction to Management (1st ed.). Yogyakarta: Depublish

Fitriastuti, Triana. 2013. The Effect of Emotional Intelligence, Organizational Commitment, and Organizational Citizenship Behavior on Employee Performance. Journal of Management Dynamics, 4(2), pp.103-114.

Available at: https://journal.unnes.ac.id/nju/index.php/jdm/article/view/2753/2813

Ghoniyah, N \& Masurip. 2011. Improved Employee Performance through Leadership, Work Environment and Commitment. Journal of Management Dynamics, 2(2), pp.118-129. Available at:

https://journal.unnes.ac.id/nju/index.php/jdm/article/view/2476/2529

Ghozali, Imam. 2016. Quantitative and Qualitative Research Designs for Accounting, Business and Other Social Sciences. Semarang: Primary Yoga.

Gibson, J.L., Ivancevich, J.M., \& Donelly JH. 2005. Organization: Behavior, Structure, Process. Translated by Nunuk Adriani. Eighth Edition. Jakarta: Literature Binarupa

Gunanjar, G.G, et. al. 2019. Supervision with Community Participation and Its Implementation in Indonesia. Journal of Supervision, 1(1), pp.18-28. Available at:

http://www.bpkp.go.id/public/upload/unit/puslitbangwas/files/Jurnal\%20Pengawas/Jurnal\%20Pengawasan_Vol\%201_No \%201_Sept\%202019.pdf

Gunawan, Imam. 2017. Introduction to Inferential Statistics. Jakarta: Rajagrafindo Perkasa.

Halidayati, Ira. 2014. The Effect of Internal Supervision, External Monitoring and Performance-Based Budgeting Implementation on Local Government Performance (Empirical Study on Payakumbuh City Regional Apparatus Work Unit). Scientific Journal of Padang State University Students. Available at: http://ejournal.unp.ac.id/students/index.php/akt/article/download/1044/738

Hartono, Tri. 2006. Evaluation of Follow-up on Audit Findings as an Element of Performance Assessment of Branch Office Management (Case Study at Bank BTN). Diponegoro University Institutional Repository. Available at: http://eprints.undip.ac.id/15918/

Hastuti, Dwi. 2018. The Effect of Motivation, Competence and Satisfaction on the Performance of Health Cadres with Work Commitment as an Intervening Variable (Study of Pagiyanten Health Center, Tegal Regency). Journal of Magisma, 6(1), pp.23-34. Available at: http://jurnal.stiebankbpdjateng.ac.id/jurnal/index.php/magisma/article/view/16

Hernawati, Sri. 2017. Research Methodology in the Health Sector: Quantitative and Qualitative. Ponorogo: Health Scientific Forum (FORIKES)

Indartono, Setyabudi. 2016. Introduction to Management: Character Inside. Yogyakarta: Yukaprint.

Irvan, R.M., \& Heryanto. 2019. The Effect Of Competence And Workload On Motivation And Its Impact On The Performance Of Civil Servants At The Regional Secretariat Of The Regency Of Dharmasraya. Archives of Business Research, 7(5), pp.134-142. Available at: http://116.203.177.230/index.php/ABR/article/view/6461/3911

Israel, Glenn D. 2003. Determining Sample Size. University of Florida.

Kawiana, I. G. P., et. al. 2018. The Influence of Organizational Culture, Employee Satisfaction, Personality, and Organizational Commitment Towards Employee Performance. International Research Journal of Management, IT and Social Sciences, 5(3), pp.35-45. Available at: http://sloap.org/journals/index.php/irjmis/article/view/166

Ministry of Cooperatives and SMEs, 2020. Strategic Plan of the Ministry of Cooperatives and SMEs for 2020 - 2024. Jakarta: Ministry of Cooperatives and SMEs.

Lee, C. W., \& Kusumah, A. 2020. Influence of Supervision on Employee Performance with Work Motivation as an Intervening Variable. Review of Integrative Business and Economics Research, 9, pp.240-252. Available at: http://sibresearch.org/uploads/3/4/0/9/34097180/riber_9-s2_39_m19-035_240-252.pdf

Lusiana, Djamhuri, A., \& Prihatiningtias, Y.W. 2017. Analysis of Follow-up on Investigation Results. Journal of Economia, 13(2). Available at: https://journal.uny.ac.id/index.php/economia/article/view/15180

Luthans, Fred. 2006. Organizational Behavior. Yogyakarta: Publisher Andi. 


\title{
International Journal of Business and Applied Social Science
}

\author{
E-ISSN: 2469-6501 \\ VOL: 8, ISSUE: 2 \\ February/2022 \\ DOI: http://dx.doi.org/10.33642/ijbass.v8n2p3 \\ (c) (7) \\ https://creativecommons.org/licenses/by/4.0/
}

Makawi, U., Normajatun, \& Haliq, A. 2015. Analysis of the Influence of Competence on the Performance of Employees of the Banjarmasin City Industry and Trade Office. Al - Ulum Social Sciences and Humanities, 1(1). Available at: https://ojs.uniska-bjm.ac.id/index.php/ALSH/article/download/307/290

Mangkunegara, AP. 2006. HR Performance Evaluation. Bandung: Refika Aditama

Martini, IAO, et. al. 2018. The Influence of Competency on Employee Performance through Organizational Commitment Dimension. IOSR Journal of Business and Management (IOSR-JBM), 20(2), pp.29-37. Available at: http://www.academia.edu/download/56829746/E2002082937.pdf

McClelland, David C. 1973. Testing for Competence Rather Than for Intelligence. Cambridge: Harvard University. McShane, Steven L., \& Glinow, M.A.V. 2010. Organizational Behavior (5th ed.). New York: McGraw Hill.

Mohson, Ali. 2006. Quantitative Analysis Techniques. Yogyakarta: Yogyakarta State University.

Nahor, J.L.B., Adriani, A., \& Nor, W. 2021. Analysis of the Completion of Follow-up to the Results of the BPK's Examination on the Performance Examination of the APIP Activities of the East Barito Regency Inspectorate. Journal of Accounting and Finance, 9(1), pp.1-16. Available at : https://ojs.unimal.ac.id/jak/article/view/3447

Napitupulu, L.A. 2017. The Effect of Organizational Commitment, Motivation and Competence on Managerial Performance at Private Hospitals in Pekenbaru City. JOM Fekon, 4(1). Available at: https://media.neliti.com/media/publications/198615-unjuk-komitmen-organizational-motivas.pdf

Nilamsari, Devitia P. 2018. Measurement of Professional Worker Performance in Service Organizations (Case Study of Salatiga City). JEMAP: Journal of Economics, Management, Accounting and Taxation, 1(1). Available at: http://journal.unika.ac.id/index.php/jemap/article/view/1588

Noor, Munawar. 2021. Novelty / Novelty in Scientific Writing Thesis / Thesis / Dissertation. Administrative Pulpit, 18(1). Available at: http://jurnal.untagsmg.ac.id/index.php/mia/article/view/2164

Nurhawa, Perizade, B., \& Hanafi, A. 2019. Monitoring and Motivation of Performance with Commitment as an Intervening Variable at the Muaradua Oku Selatan Hospital. E-Journal of Management, 8(12), pp.7239-7259. Available at: https://ojs.unud.ac.id/index.php/Management/article/view/52639

Patulak, M. E., Thoyib, A., \& Setiawan, M. 2013. The Role of Organizational Commitment as Mediator of Organizational Culture and Employees' Competencies on Employees' Performances (A Study on Irrigation Area Management in Southeast Sulawesi). Journal of Economics and Sustainable Development, 4(5), pp. 166-175. Available at: https://core.ac.uk/download/pdf/234645897.pdf

Regulation of the Supreme Audit Agency of the Republic of Indonesia Number 1 of 2017. Regarding State Audit Standards. Jakarta: Supreme Audit Agency.

Regulation of the Supreme Audit Agency of the Republic of Indonesia Number 2 of 2017. Regarding Monitoring the Implementation of Follow-up on the Recommendations of the Audit Board of the Republic of Indonesia. Jakarta: Supreme Audit Agency.

Regulation of the Minister of Cooperatives and SMEs Number 1 of 2021. Regarding the Organization and Work Procedure of the Ministry of Cooperatives and Small and Medium Enterprises. Jakarta: Ministry of Cooperatives and SMEs.

Regulation of the Minister of Cooperatives and SMEs Number 09/Per/M.KUKM/IX/2015. Regarding Procedures for Implementing Internal Supervision in the Ministry of Cooperatives and SMEs. Jakarta: Ministry of Cooperatives and SMEs.

Regulation of the Minister of Cooperatives and SMEs Number 08/Per/M.KUKM/IX/2015. About the Organization and Work Procedures of the Ministry of Cooperatives and Small and Medium Enterprises. Jakarta: Ministry of Cooperatives and SMEs.

Regulation of the Minister of State for Administrative Reform Number: PER/09/M.PAN/5/2007. Regarding General Guidelines for Determining Key Performance Indicators in Government Agencies. Jakarta: State Minister for State Apparatus Empowerment.

Regulation of the Minister of State for the Empowerment of State Apparatus Number 09 of 2009. Concerning General Guidelines for Monitoring, Evaluation, and Reporting of Follow-Ups on the Results of Functional Supervision. Jakarta: State Minister for State Apparatus Empowerment. 


\title{
International Journal of Business and Applied Social Science
}

\author{
E-ISSN: 2469-6501 \\ VOL: 8, ISSUE: 2 \\ February/2022 \\ DOI: http://dx.doi.org/10.33642/ijbass.v8n2p3 \\ (c) (7) \\ https://creativecommons.org/licenses/by/4.0/
}

Regulation of the Minister of State Apparatus Empowerment and Bureaucratic Reform of the Republic of Indonesia Number 38 of 2017. Regarding Competency Standards for State Civil Apparatus Positions. Jakarta: Ministry of Administrative Reform and Bureaucratic Reform.

Government Regulation of the Republic of Indonesia Number 60 of 2008. Concerning the Government's Internal Control System. Jakarta: State Secretariat.

Government Regulation of the Republic of Indonesia Number 101 of 2000. Regarding Education and Training for Civil Servants. Jakarta: State Secretariat.

Presidential Regulation Number 96 of 2020. Concerning the Ministry of Cooperatives and Small and Medium Enterprises. Jakarta: State Secretariat.

Pongoliu, R.R, Saerang, D., \& Manossoh, H. 2017. Analysis of Obstacles in Completion of Follow-Ups on BPK Examination Results in the Gorontalo Provincial Government. Journal of Accounting and Auditing Research "Goodwill”, 8(1). Available at: https://ejournal.unsrat.ac.id/index.php/goodwill/article/view/15254

Posuma, Christilia O. 2013. Competence, Compensation, and Leadership Their Influence on Employee Performance at Ratumbuysang Hospital Manado. EMBA Journal, 1(4). Available at:

https://ejournal.unsrat.ac.id/index.php/emba/article/view/2748

Purnomo, R.A. 2016. Economic and Business Statistical Analysis with SPSS (1st ed.). Ponorogo: Wade Group.

Putera, M.A.P. 2019. Follow-up Evaluation of BPK Audit Results at Government Agencies in Makassar City. Digital Library of Muhammadiyah University of Makassar. Available at:

https://digilib.unismuh.ac.id/document/detail/7916/

Son, Adi. 2013. Knowledge Management as an Effort to Develop Learning Organizations in Educational Institutions. Journal of An Nur, 5(1). Available at : http://ejournal.iiq-annur.ac.id/index.php/An-Nur/article/download/27/27

Putri, Eka M. 2015. The Influence of Human Resource Competency Factors on Employee Performance in the Implementation of e-Procurement (Case Study at the Ministry of Public Works). thesis. Ten November Institute of Technology Surabaya.

Rantelangi, C., et. al. 2017. The Influence of Organizational Commitment, Auditor Independence, Internal Control, and Ethical Leadership in Good Governance and Organizational Performance, Good Governance and Organizational Performance. In Mulawarman International Conference on Economics and Business (MICEB 2017). Atlantis Press. Available at : https://www.atlantis-press.com/proceedings/miceb-17/25892441

Rantesalu, A., et. al. 2016. The Effect of Competence, Motivation and Organizational Culture on Employee Performance: the Mediating Role of Organizational Commitment. Quest Journals, Journal of Research in Business and Management, 4(9), pp.8-14. Available at : https://osf.io/preprints/inarxiv/m7wqs/

Ridlo, Aflakhur. 2017. Increasing Public Sector Productivity and Performance (Improving Public Sector Productivity and Performance). Mercubuana Digital Library, pp. 227-239. Available at:

http://digilib.mercubuana.ac.id/manager/t!@file_article_abstrak/Isi_Artikel_854026487799.pdf

Rifky. 2018. Don't underestimate the follow-up to BPK's findings. [on line] https://government.id/isi/judul/jangan_Sepelekan_Tindak_Lanjut_Temuan_BPK [accessed September 15, 2018]

Robbins, S.P., \& Coulter, M. 2012. Management (11th ed.). New Jersey: Pearson.

Rothwell, W.J., \& Kazanas, H.C. 2003. Planning \& Managing Human Resources (2nd ed.). Massachusetts: HRD Press, Inc.

Sahusilawane, Wildoms. 2020. The Effect of Information Technology, Organizational Commitment, Internal Control and Good Corporate Governance Principles on Organizational Performance. International Journal of Social Science and Business, 4(2), pp.197-210. Available at: https://ejournal.undiksha.ac.id/index.php/IJSSB/article/view/24524/15331

Salthory, A.D. 2014. The Effect of Government Supervision on the Implementation of the National Community Empowerment Program (PNPM) - Rural Mandiri (Study on the Community Empowerment Agency and Village/Kelurahan Government in Menggala District, Tulang Bawang Regency). UNILA Digital Repository. Available at: http://digilib.unila.ac.id/393/ 


\title{
International Journal of Business and Applied Social Science
}

\author{
E-ISSN: 2469-6501 \\ VOL: 8, ISSUE: 2 \\ February/2022 \\ DOI: http://dx.doi.org/10.33642/ijbass.v8n2p3 \\ (c) (i) \\ https://creativecommons.org/licenses/by/4.0/
}

Sapitri, Ranty. 2016. The Effect of Organizational Commitment on the Performance of Employees of the State Electricity Company in Pekanbaru Area. FISIP Student Online Journal, 3(2). Available at: https://jom.unri.ac.id/index.php/JOMFSIP/article/view/10663

Sari, R.NI., \& Hadijah, H.S. 2016. Improved employee performance through job satisfaction and work discipline. Journal of Office Management Education, 1(1). Available at: https://ejournal.upi.edu/index.php/jpmanper/article/download/3389/2381

Sari, F.H. 2014. Analysis of the Supervision Function of the Department of Transportation in Controlling Public Transportation in Pekanbaru City. Sultan Syarif Kasim State Islamic University Riau Repository. Available at: http://repository.uin-suska.ac.id/4067/

Sarwono, Jonathan. 2007. Pathway Analysis for Business Research with SPSS (1st ed.). Yogyakarta: Publisher Andi.

Sekaran, U., \& Bougie, R. 2016. Research Methods for Business: A Skill Building Approach (7th ed.). United Kingdom: Wiley.

Setyaningsih, Sri. 2020. Strengthening Educational Management Resources Through Path Analysis \& the Sitorem Method. Bandung: Alphabeta Publisher.

Simanjuntak, Payaman J. 2015. Human Resource Management Teaching Materials. Jakarta: Krisnadwipayana University.

Spencer, L.M., \& Spencer, S.M. 1993. Competence at Work: Models for Superior Performance. Canada: John Wiley \& Sons, Inc.

Sudirman, I \& Dalyodi, M. 2013. The Influence of Work Ability, Work Motivation and Work Discipline on the Performance of Inspectorate Employees of Belitung Regency. Journal of Economics, Business \& Entrepreneurship, 7(1), pp.10-19. Available at: http://jurnal.stiepas.ac.id/index.php/jebe/article/view/25

Sugiyono. 2015. Educational Research Methods (22nd ed.). Bandung: Alphabeta.

Sujana, Eddy. 2012. The Influence of Competence, Motivation, Conformity of Roles and Organizational Commitments on the Performance of the Internal Auditors of the Regency Government Inspectorate (Study at the Office of the Inspectorate of Badung and Buleleng Regencies). Scientific Journal of Accounting and Humanika, 2(1). Available at : https://ejournal.undiksha.ac.id/index.php/JJA/article/view/551

Suliyanto. 2011. Differences in views of the Likert Scale as an Ordinal Scale or an Interval Scale. Proceedings of the 2011onegoro University Statistics National Seminar, pp.51-60. Available at:

http://eprints.undip.ac.id/33805/

Suwiknyo, E. 2017. Follow-up to BPK's Recommendations: Compliance is Still Low. [on line]. http://kalimantan.bisnis.com/read/20171004/433/695532/tindaklanjut-rekomendasi-bpk-kepatuhan-masih-low [accessed September 13, 2018]

Syahyuni, Dedy. 2016. Relationship between Competence and Employee Performance in Service Companies.

National Seminar on Computer Science and Technology, pp.27-34. Available at:

https://konference.nusamandiri.ac.id/proceeding/index.php/sniptek/article/view/148/148

The Institute of Internal Auditors. 2009. Practice Advisory 2500-1: Monitoring Progress. Florida: The Institute of Internal Auditors.

1945 Constitution of the Republic of Indonesia.

Law of the Republic of Indonesia Number 15 of 2004. Regarding Audit of State Finance Management and Accountability. Jakarta: State Secretariat.

Verma, H.N., Takale, R. \& Ghadoliya, M.K. 2013. Principles of Management. Bavdhan: Universal Training Solutions Private Limited.

Wardhana, G.A.S., Rasmini, N.K., \& Astika, I.B.P. 2015. The Effect of Competence on Performance Accountability of Government Agencies with Organizational Commitment as a Moderating Variable. E-Journal of Economics and Business, Udayana University, 4(9), pp. 571-598. Available at: https://simdos.unud.ac.id/uploads/file_penelitian_1_dir/dd00c989c0a08b4eb16abfb8fb4bc803.pdf

Wibowo. 2017. Performance Management (Fifth Edition). Jakarta: Raja Grafindo Persada.

Wijaya, C. \& Rifa'i, M. 2016. Fundamentals of Management: Optimizing Organizational Management Effectively and Efficiently. Medan: Perdana Publishing. 


\section{International Journal of Business and Applied Social Science}

E-ISSN: 2469-6501

VOL: 8, ISSUE: 2

February/2022

DOI: http://dx.doi.org/10.33642/ijbass.v8n2p3

Woodall, J. \& Winstanley, D. 1998. Management Development: Strategy and Practice. Blackwell Publishers: Oxford.

Yamali, F.R. 2017. The Effect of Compensation and Competence on Organizational Commitment and Its Implications on the Performance of Experts in Construction Services Companies in Jambi Province. Economists: Journal of Economics and Business, 1(1), pp.213-222. Available at: https://media.neliti.com/media/publications/225665-elektron-kompetensi-dan-kompetensi-terha-a30f6fb4.pdf

Yani, A.S., \& Kristanto, G. 2016. The Influence of Organizational Culture and Supervision on Employee Performance with Organizational Commitment as Moderating Variable in Kopega PLN Priok Sector Jakarta. Media Management Services, 3(2), pp.21-32. Available at: http://journal.uta45jakarta.ac.id/index.php/MMJ/article/view/700

Zustiana. 2019. Influence of Self Efficacy, Family Environment on Achievement Motivation with Study Habits as Mediating Variable. Journal of Economics, Business and Accounting (JEBA), 21(2). Available at: ttps://www.google.com/url?sa=t\&rct=j\&q=\&esrc=s\&source=web\&cd=\&cad=rja\&uact=8\&ved=2ahUKEwiX2JH3pDyAhXXYysKHZPUBfE4ChAWMAF6BAgEEAM\&url=http\%3unjsoed.Fac2.

.id\%2Findex.php\%2Fjeba\%2Farticle\%2FviewFile\%2F1325\%2F1392\&usg=AOvVaw1ThFsijV4TZ-nrt5RBTgqt 